論文

\title{
$\mathrm{Cr}-\mathrm{Mo}$ 鋳鋼の清水中疲労強度に及妾す表面仕上げの 影響およびインヒビターによる腐食疲労防止効果
}

\author{
三浦 健 蔵* 熊 田 誠** 大 井 利 継*
}

\section{Effect of Surface Condition on Fatigue Strength of Cr-Mo Cast Steel in Fresh Water and Corrosion Fatigue Prevention Using Inhibitor}

by

\section{Kenzou Miura, Makoto Kumada and Toshitsugu OHI}

(Tamano Laboratory, Mitsui Engineering and Shipbuilding Co. Ltd., Tamano)

The effect of surface condition on fatigue strength, corrosion fatigue prevention and the corrosion fatigue damage which occurred in the specimen were investigated in fresh water and aqueous solution containing sodium nitrite inhibitor at $80^{\circ} \mathrm{C}$ using relatively large $\mathrm{Cr}-\mathrm{Mo}$ cast steel specimens.

A finely machined specimen (surface roughness, $R<2 \mathrm{~s}$ ), a roughly machined specimen $(R \simeq 20 \mathrm{~s})$ and a shot blusted cast skin specimen had a clear fatigue limit in air. The fatigue limit of the roughly machined specimen fell to about $90 \%$ of that of the finely machined specimen, but the fatigue limit of the shot blusted cast skin specimen became very high compared with those of the finely and the roughly machined specimens. The fatigue strengths of the finely and the roughly machined specimens in fresh water at $80^{\circ} \mathrm{C}$ were the same level. Many corrosion pits and microcracks occurred on both the finely and the roughly machined specimens. The shape of microcracks was semielliptical when the stress amplitude was relatively high, but the microcracks were combined with each other and were stretched along the surface of the specimen when the stress amplitude was low. The fatigue strengths of the finely and the roughly machined specimens in aqueous solution containing. sodium nitrite inhibitor at $80^{\circ} \mathrm{C}$ had the same level of fatigue limit as those in air, and corrosion pits and microcracks were not observed. On the other hand, the behavior of the fatigue strength of the shot blusted cast skin specimen in fresh water and aqueous solution containing sodium nitrite inhibitor at $80^{\circ} \mathrm{C}$ was different from that of the machined specimens.

(Received Apr. 12, 1984)

キー・ワード：腐食疲労，インヒビター，表面仕上げ，Cr-Mo 鋳鋼

\section{1 緒} 言

舶用ディーゼル機関は低燃費化，省エネルギ化とい ら時代の要請に即応してロングストローク化，静圧過 給化され，またシリンダ筒内最高圧力の上昇および高 温冷却化の傾向に伴い，燃焼室壁部材はますます苛酷 な条件にさらされるよらになった。このよらな状況に 対して, シリンダカバーでは設計応力の軽減, 材質の 向上のほか，現在ボアクーリング方式を採用し，冷却 水中には腐食生成物付着による冷却效率の低下や腐食 疲労損傷を防止するため，覀硝酸塩系インヒビターの 添加が行われている. しかし，ディーゼル機関の長期 信頼性向上をはかるには，実働環境を模した条件で試

$†$ 原稿受理 昭和59年 4 月 12 日

* 正会 員 三井造船(株)玉野研究所 玉野市玉原

** 三井造船(株)玉野研究所 玉野市玉原
験を実施し, 燃焼室壁部材の腐食疲労強度とインヒビ ターの腐食疲労防止效果を正確に評価する必要がある.

そこで本実験では，此較的大型の試験片について腐 食疲労試験の可能な試験装置を製作し，腐食疲労強度 に及ぼす表面仕上げの影響，インヒビターの腐食疲労 防止効果, および試験片に生じた腐食㾉労損傷につい て検討したので，その結果について報告する。

\section{2 実 験 方 法}

\section{$2 \cdot 1$ 供試材および試験片}

供試材は，舶用ディーゼル機関のシリンダカバー， ピストンクラウンなど然焼室壁部材に広く用いられて いる $\mathrm{Cr}-\mathrm{Mo}$ 鋳鋼で, 試験片の鋳造方案を Fig. 1 に 示す. 供試材は $1050{ }^{\circ} \mathrm{C}, 2$ 時間保持油焼入れ後 $690^{\circ} \mathrm{C}$, 2 時間保持炉冷の熱処理を行った. 熱処理後すべての 供試材は，鋳物砂落しおよび脱スケールのためショッ 
(a)

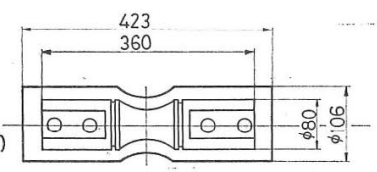

(b)

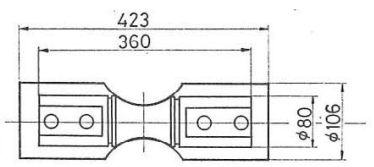

(a) Machined specimen.

(b) Cast skin specimen.

Fig. 1. Casting design of fatigue specimen.

Table I. Chemical composition of specimen (wt $\%$ ).

\begin{tabular}{c|c|c|c|c|c|c}
\hline $\mathrm{C}$ & $\mathrm{Si}$ & $\mathrm{Mn}$ & $\mathrm{P}$ & $\mathrm{S}$ & $\mathrm{Cr}$ & $\mathrm{Mo}$ \\
\hline 0.18 & 0.45 & 0.77 & 0.011 & 0.011 & 0.73 & 0.36 \\
\hline
\end{tabular}

Table II. Mechanical properties of specimen.

\begin{tabular}{c|c|c|c|c}
\hline $\begin{array}{c}\text { Yield stress } \\
\left(\mathrm{kg} / \mathrm{mm}^{2}\right)\end{array}$ & $\begin{array}{c}\text { Tensile } \\
\text { strength } \\
\left(\mathrm{kg} / \mathrm{mm}^{2}\right)\end{array}$ & $\begin{array}{c}\text { Elongation } \\
(\%)\end{array}$ & $\begin{array}{c}\text { Reduction } \\
\text { of area } \\
(\%)\end{array}$ & $\begin{array}{c}\text { Brinell } \\
\text { hardness }\end{array}$ \\
\hline 45 & 60 & 26 & 60 & 182 \\
\hline
\end{tabular}

ト・ブラストを施した. Table I, II に供試材の化学 組成と機械的性質を示した。

試験部径 $\phi 50 \mathrm{~mm}$ の比較的大型の試験片を疲労試 験片とし，その形状，寸法をFig. 2 に示した。試験 片試験部の表面仕上げ方法は 3 種類で，機椷加工によ り表面粗さ $2 \mathrm{~s}$ 以下に仕上げた精仕上試験片と表面粗 さ 20s 程度にバイトで仕上げた粗仕上試験片 (Fig. 1 (a)），抢よび試験片つか又部のみ機械加工し，試験片 試験部に鋳肌を残した鋳肌付試験片（Fig.1 (b)）であ る. 前述のよらに熱処理後鋳物仯落しのため, 供試材 にショット・ブラストを施している. 機械仕上げ試験 片では供試材から $13 \mathrm{~mm}$ 以上機械加工しているが, 鋳肌付試駼片試験部の鋳肌面はショット・ブラストの 影響がそのまま残っている。な和鋳肌付試験片には大 きなブローホールや引け巣が存在したので, 試験部近 傍に存在したものは不健全材として除外し, ‡た鋳込 久の際生じたバリは疲労き裂発生に影響しないよう真 横にくるようにして試験片を切り出した. Fig. 3 は痒 労試験片試験部表面粗さの測定結果の一例で，鋳肌付 試験片の最大表面粗さは 200s 程度である，各試験片 試験部の断面の様相を Fig. 4 に示した。機械仕上げ 試験片試験部 (Fig. 4(a)，(b)) に比べ鋳肌付試験片試験 部 (Fig. 4 (c), (d)) には表面のら初りが存在し, 試験部 直径にかなりのばらつきがあったので，鋳肌付試験片 では破断試験部の直径から応力を計算した。

\section{$2 \cdot 2$ 疲学試験}

(a)

(b)

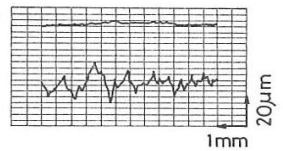

(c)

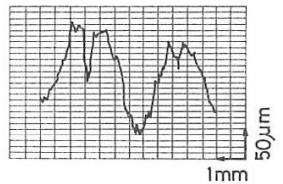

(a) Finely machined specimen.

(b) Roughly machined specimen.

(c) Cast skin specimen.

Fig. 3. Example of surface roughness of fatigue specimen.

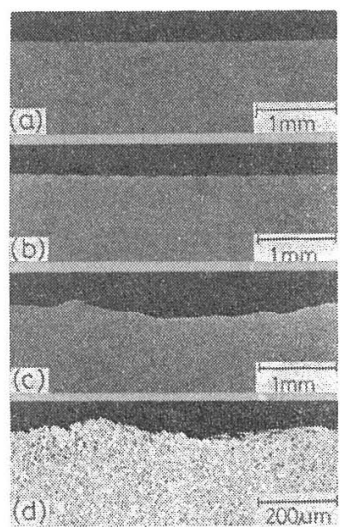

(a) Finely machined specimen.

(b) Roughly machined specimen.

(c), (d) Cast skin specimen.

Fig. 4. Surface appearance of cross-section.

塞験に用いた試験機は電気油圧サーボ型アクチュエ 一夕（島津製作所(株)製 Lab. 5 型）を取り付けそ平 面曲げ装置で，本試験 装置の最大容量は $125 \mathrm{~kg} ・ \mathrm{~m}$ である.疲労試験はすべて荷重制御とし，応力波形は 完全片振り正弦波で，繰返し速度は $10 \mathrm{~Hz}$ である。腐 食疲労試験では，Fig. 5 に腐食水の循環系を示すよう に試験片にゴム製の㕍食槽を装着し， $80^{\circ} \mathrm{C} \pm 2{ }^{\circ} \mathrm{C} に$ 加 熱した溶液を $2 l / \mathrm{min} の$ 流量で連続供給した。試験溶 液はイオン交換水に $\mathrm{Cl}^{-}$イオン, $\mathrm{HCO}_{3}^{-}$イオン, $\mathrm{SO}_{4}{ }^{2-}$ イオン $\left(\mathrm{NaCl}, \mathrm{NaHCO}_{3}, \mathrm{Na}_{2} \mathrm{SO}_{4}\right.$ にて調整 $)$ をとれぞれ $100 \mathrm{ppm}$ 添加した ASTM 腐食水とこれ に市販の覀硝酸塩系インヒビター（以下， $\mathrm{NaNO}_{2}$ と 記す）学防食限界量以上の $3000 \mathrm{ppm}$ 添加したるので, 試験溶液の全量は約 $60 \ell$ である。

疲労試験後, 光学顥微鏡亡走査型電子顕微鏡（日立 製作所 (株) 製 HSM-2A 型) 老用いて疲学試験片の 表面，断面括よび破面を観察した。な沏試験片表面に 発生した赤さびは $10 \% \mathrm{H}_{2} \mathrm{SO}_{4}$ 溶液， $20 \% \mathrm{HNO}_{3}$ 溶液 にとれぞれ数秒間浸漬して除去した。

3 平面曲げ試験装置の製作

容量 5 トンの電気油圧サーボ型アクチュエータを取 


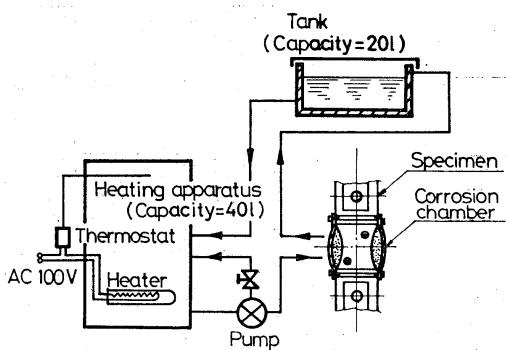

Fig. 5. Circulating system of solution used in corrosion fatigue tests.

り付けた平面曲げ試験装置の概略図を Fig. 6 亿示し た。試験装置はシェンク式平面曲げ試験機を応用した もので，試験片の一端を固定し，他端を試験片取付け 装具, 連接棒, ロードセルを介してアクチュエータで 駆動する．試験部径 $\phi 50 \mathrm{~mm}$ の試験片に負荷される 応力 $\sigma$ と負荷荷重 $P$ との関係を実験的江求め, 以後次

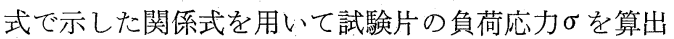
した。

$$
\sigma=19.9 \times 10^{-3} \times P\left(\mathrm{~kg} / \mathrm{mm}^{2}\right)
$$

アクチュエータの許容ストロークは繰返し速度 10 $\mathrm{Hz}$ のとき約 $\pm 2.0 \mathrm{~mm}$ であり，試験片に疲労き裂が 発生，進展して試験片のたわみが増大すると，アクチ ュニータのストローク量が限界に達して試験装置は停 止する，試験装置が停止したとき，試験片の破断面は 全断面の $30 \%$ 以上を占め，末た荷重制御試験であるの で，完全に試験片が破断するまでの残存き裂進展絽返 し数は非常に少ないと考光られる.したがって本実験

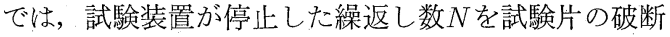
繰返し数 $N_{f}$ と定義した.

\section{4 実験結果および考察}

\section{$4 \cdot 1$ 疲労強度に及ぼす表面仕上げの影響}

4.1 1 大気中疲労強度 精仕上, 粗仕上, 拈よ びショット・ブラストされた鋳肌付試験片の大気中疲 労 $S-N$ 線図を Fig. 7 亿示す. 各試験片には明りょう な疲労限度 $\sigma_{w}$ が存在し, 負荷応力振幅 $\sigma_{a}$ と破断繰 返し数 $N_{f}$ との間には両対数表示で直線関係が認めら れた. 表面粗さを $2 \mathrm{~s}$ 以下に仕上げた精仕上試験片と 表面粗さ $20 \mathrm{~s}$ 程度に仕上げた粗仕上試験片の疲労強度 を比較するを，粗仕上試験片の疲労強度はわずかに低 下し，粗仕上試験片の疲労限度は精仕上試験片のそれ の約 $90 \%$ に低下した. この疲労強度低下は試験部表面 粗さの影響によるものと考光られ，従来報告されてい る表面仕上げに関する実験結果とほぼ一致している。

つぎに疲労強度に及ぼす鋳肌の影響について検討す る. 鋳肌表面にはマクロな凹凸や鋳造欠陥が存在し， また鋳肌表面近傍に引張応力が残留するため，疲労強 度は一般に低下する。一例として，Cr-Mo 鋳鋼の鋳
肌による曲げ疲労強度は約30\%低下したとの報告があ る.

しかしながら，本実験 では Fig.7“から明らかなよ らに，機械加工を施した精仕上，粗仕上試験片に比べ 鋳肌付試験片の疲労強度は著しく上昇し, 疲労限度は 精仕上試験片の乞れの $25 \%$ 程度上昇した。鋳肌付試験 片の疲労強度上昇の原因は次のように考光られる。

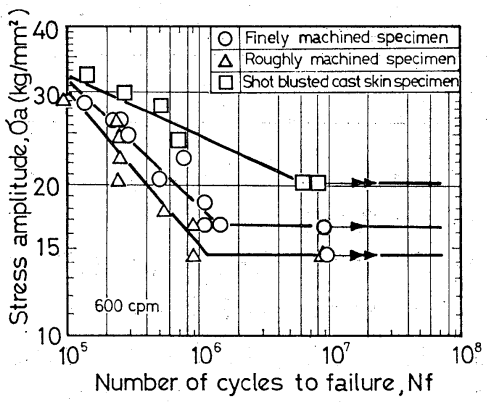

Fig. 7. $S-N$ curves for finely machined, roughly machined and shot blusted cast skin specimen of $\mathrm{Cr}-\mathrm{Mo}$ cast steel in air.

ず試験部近傍の鋳肌表面にマクロな凹凸や欠宿が存在 する場合には，不健全材として除外したため，疲労き 裂発生に対するこれら欠陥の影響が少なかったことが あげられる．試験後の破面からもこの点を確認した。 つぎに試験片の鋳造，熱処理後砂落し，スケール除去 を目的に約 30 分間ショット・ブラスト（ショット径 1 ３ mm） が施されているので, ショット・ブラスト の影響が考兄られる、X線応力測定装置を用いて, 各 試験片の試験片表面層（表面から 10 15 $\mu \mathrm{m}$ 深さの位 置）と $150 \mu \mathrm{m}$ 深さの位置に括ける軸方向残留応力を 測定した。 その結果を. Table III に示す．表面近傍 に和㳊残留応力は， $-20 \sim-25 \mathrm{~kg} / \mathrm{mm}^{2}$ で，表面 仕上げの影響はほとんど認められなかった。，しかし試 験片表面から. $150 \mu \mathrm{m}$ の深さに打仔る残留応力は, 精 仕上，粗仕上試験片について $-0.1 \mathrm{~kg} / \mathrm{mm}^{2},-5.1$

*1 樑さは Jacquet 浴で電解研摩により加工層を然ひずみ的に溶解 して調整した 
Table III. Residual stress in specimen surface.

\begin{tabular}{l|c|c}
\hline $\begin{array}{r}\text { Residual } \\
\text { stress, } \sigma_{R}\end{array}$ & $\begin{array}{c}\text { Surface } \\
(10 \sim 15 \mu \mathrm{m})\end{array}$ & $\begin{array}{l}150 \mu \mathrm{m} \text { from } \\
\text { surface }\end{array}$ \\
\hline Finecimen machine & $-21.6 \mathrm{~kg} / \mathrm{mm}^{2}$ & $-0.1 \mathrm{~kg} / \mathrm{mm}^{2}$ \\
Roughly machine & $-20.5 \mathrm{~kg} / \mathrm{mm}^{2}$ & $-5.1 \mathrm{~kg} / \mathrm{mm}^{2}$ \\
Shot blusted cast skin & $-24.9 \mathrm{~kg} / \mathrm{mm}^{2}$ & $-31.9 \mathrm{~kg} / \mathrm{mm}^{2}$ \\
\hline
\end{tabular}

$\mathrm{kg} / \mathrm{mm}^{2}$ であるのに対し，鋳肌付試験片では -31.9 $\mathrm{kg} / \mathrm{mm}^{2}$ であり, 鋳肌付試験片の王縮残留応力值は表 面層を切削して除いた機械仕上げ試験片よりも25 kg/ $\mathrm{mm}^{2}$ 以上大きいことがわかった.

$4 \cdot 1 \cdot 2$ 清水中疲労強度 Fig. 8 10 1 は, $80^{\circ} \mathrm{C} \mathrm{A}$ $\mathrm{STM}$ 腐食水とインヒビター $\mathrm{NaNO}_{2} 3000 \mathrm{ppm}$ を添 加した溶液中に和ける精仕上, 粗仕上括よびショット ・ブラストされた鋳肌付試験片の疲労試験結果である. Fig. 8，9 によれば, $80^{\circ} \mathrm{C}$ ASTM 腐食水中における精 仕上試験片と粗仕上試験片の疲労強度はほぼ同程度で あり, 腐食疲労強度に及ぼす表面粗さの影響㥜めら れなかった. 腐食疲労強度は繰返し数 $2 \times 10^{6}$ 回で大気 中疲労限度の $70 \sim 75 \%$ に また繰返し数 $10^{7}$ 回で大気 中瘦労限度の $60 \%$ 以下に低下している. な特前報で報 告した小型試験片（試験部径 $\phi 12 \mathrm{~mm}$ ）についての回 転曲げ疲労試験結果 (繰返し速度 $170 \mathrm{cpm}$ ) と比較す ると, $80^{\circ} \mathrm{CASTM}$ 腐食水中に拈ける大型試験片（試 験部径 $\phi 50 \mathrm{~mm}$ ) の疲労強度は, 低応力側で大きく低 下寸る傾向にある. $80^{\circ} \mathrm{C}$ ASTM 腐食水に $\mathrm{NaNO}_{2}$ $3000 \mathrm{ppm}$ を添加した溶液中では, 精仕上試験片, 粗 仕上試験片の疲労強度は大気中疲労強度にほぼ回復し, 大気中と同程度の疲労限度が存在した. 機械加工を施 した試験片では $\mathrm{NaNO}_{2}$ による非常に良好な腐食疲労 防止効果が認められた. Fig. 10 はショット・ブラス トされた鋳肌付試験片の疲労試験結果で, 精仕上試験

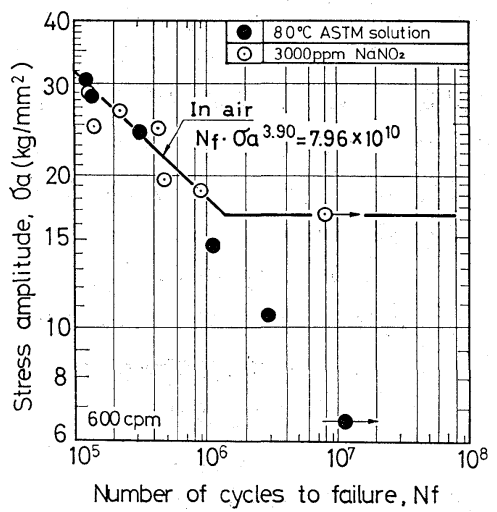

Fig. 8. Fatigue data for finely machine specimen $(R<2 \mathrm{~s})$ of $\mathrm{Cr}-\mathrm{Mo}$ cast steel in ASTM solution and solution containing sodium nitrite inhibitor at $80^{\circ} \mathrm{C}$.

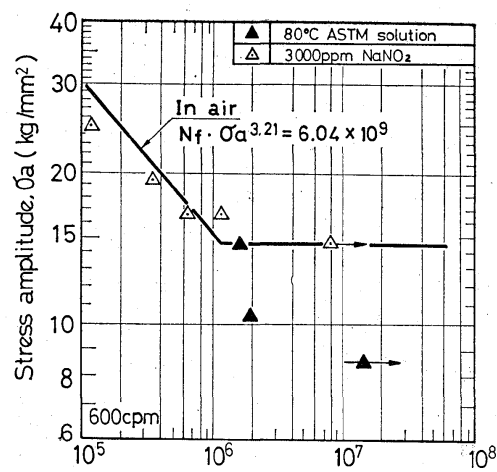

Number of cycles to failure, $\mathrm{Nf}$

Fig. 9. Fatigue date for roughly machined specimen $(R \simeq 20 \mathrm{~s})$ of $\mathrm{Cr}-\mathrm{Mo}$ cast steel in ASTM solution and solution containing sodium nitrite inhibitor at $80^{\circ} \mathrm{C}$.

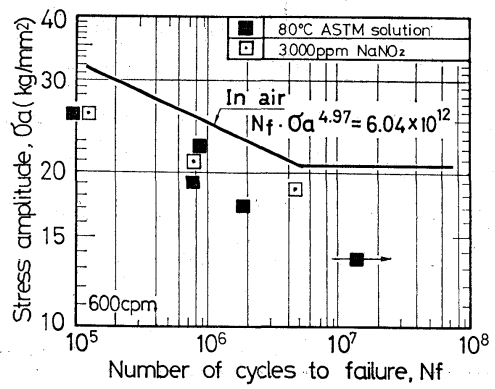

Fig. 10. Fatigue data for shot blusted cast skin specimen of Cr-Mo cast steel in ASTM solution and solution containing sodium nitrite inhibitor at $80^{\circ} \mathrm{C}$.

片，粗仕上試験片の結果と異なった傾向を示している. $80^{\circ} \mathrm{C}$ ASTM 腐食水中に特壮る疲労強度は, 大気中疲 労強度と比べると高応力側と低応力側でいずれも低下 乙, 繰返し数 $2 \times 10^{6}$ 回, $10^{7}$ 回の疲労強度は大気中疲 労限度の約 $80 \% ， 70 \%$ に低下した. 鋳肌試験片の腐食 疲労強度は機械加工を施した精仕上, 粗仕上試験片の それより若干高く，大気中の場合と同様ショット・ブ ラストの影響と考えられる. 後述するように繰返し数 $2 \times 10^{6}$ 回, $10^{7}$ 回に和壮る腐食疲労損傷の観察結果か ら, 最大腐食ピットが $150 \mu \mathrm{m}$ 程度であり, 鋳肌付試 験片では表面から $150 \mu \mathrm{m}$ に打ける䇢所で $-31.9 \mathrm{~kg} /$ $\mathrm{mm}^{2}$ の残留応力が確認された. また, 鋳肌付試験片の 低下率は機械仕上げ試験片に比べ低応力側で比較的少 なく, 従来報告されている鋳肌材についての腐食疲労 試験結果と一致している.

ところでショット・ブラストされた鋳肌面には，マ クロな鋳造欠陥のほか Fig. 4 (d)に鋳肌面の顕微鏡写 真を示したように切欠き状の微細な表面欠陥が存在し ている. $\mathrm{NaNO}_{2}$ 添加溶液中に扣ける鋳肌付試験片の 
鋳肌面様相は溶液中への浸漬前後で洼とんど変らなか ったが，鋳肌面の一部にスポット状腐食生成物が認め られ，局部的な腐食を生じた可能性があった. $\mathrm{NaNO}_{2}$ $3000 \mathrm{ppm}$ 添加 $80^{\circ} \mathrm{C}$ ASTM 腐食水中に抢けるショッ ト・ブラストされた鋳肌付試験片の痩労強度は, Fig. 10 に示したよらに $\mathrm{NaNO}_{2}$ を含まない腐食水中の疲労 強度とほぼ同程度であった。このことから，インヒビ ターを添加した溶液中に特ける鋳肌付試験片では，鋳 肌面の欠陷部に局部的な腐食が発生し, 瘏学强度が低 下したことが考光られる。

な特試験片の表面に鋳肌あるいは微細な表面欠樎が 存在する場合のインヒビターによる腐食痩学防止效果 については，次報で検討する宁定である。

\section{$4 \cdot 2$ 試験片表面, 断面および破面の観察}

$80^{\circ} \mathrm{C}$ ASTM 腐食水物上び $3000 \mathrm{ppm} \mathrm{NaNO}_{2}$ 添加 水中で痩学試験を実施した試験片について, 主き裂近 傍試験部の表面初よび軸方向断面の腐食損傷を観察し

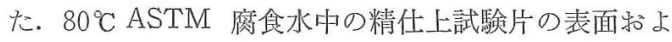
び断面の観察結果の一例を Fig. 11 に示す. Fig. 11 (a) は応力振幅 $\sigma_{a}=30.5 \mathrm{~kg} / \mathrm{mm}^{2}$, 破断繰返し数 $N_{f}=$ $1.31 \times 10^{5}$ 回, Fig. 11 (b)は $\sigma_{a}=14.5 \mathrm{~kg} / \mathrm{mm}^{2}, N_{f}=$ $1.11 \times 10^{6}$ 回, Fig. 11 (c)は $\sigma_{a}=6.5 \mathrm{~kg} / \mathrm{mm}^{2}, N_{f}>$

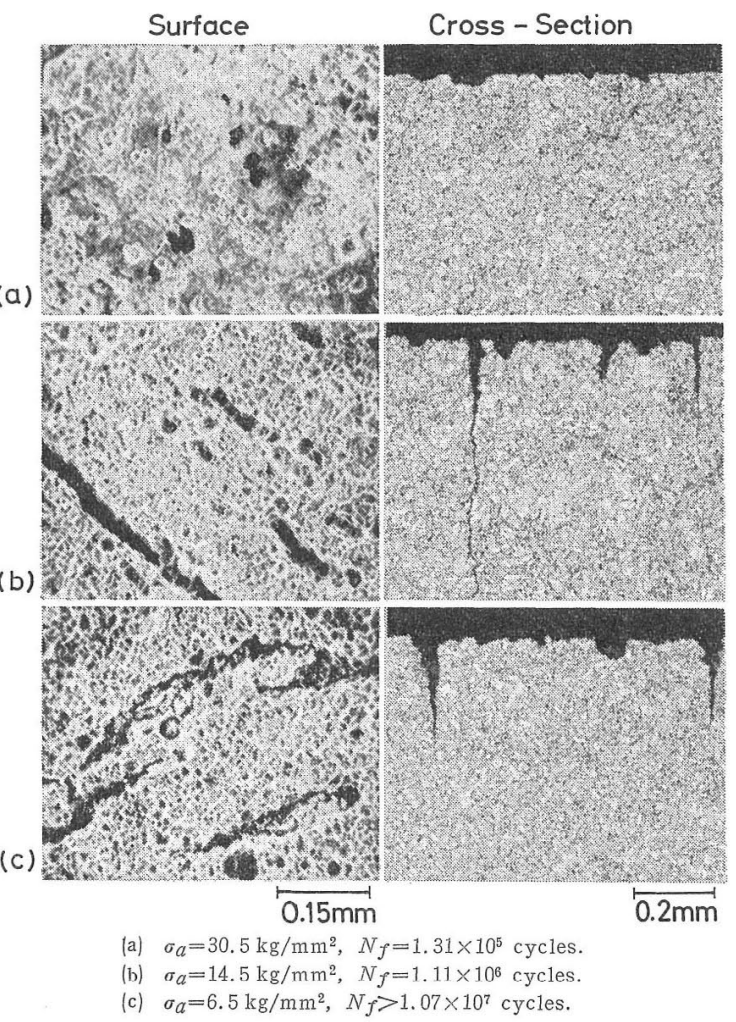

Fig. 11. Specimen surface and cross-section of finely machined specimen fatigue-tested in ASTM solution at $80^{\circ} \mathrm{C}$.
$1.07 \times 10^{7}$ 回（未破断）の結果である. 腐食ピットは 高応力側, 低応力側いずれの試験片の場合にも認めら れる. 特に低応力側では腐食ピットは互いに合体し, また腐食ピット底から微視き裂が発生しているため, 腐食ピットと微視き裂とは区別しにくい。試験部断面 の観察から，腐食ピットについては損傷部開口量が10 $\mu \mathrm{m}$ 以上，あるいは開口量 $5 \mu \mathrm{m}$ 屯でで微視き裂との 区別が明らかな損傷と定義し，一方微視さ裂について

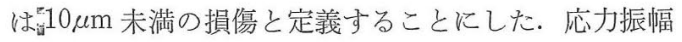
$\sigma_{a}=30.5 \mathrm{~kg} / \mathrm{mm}^{2}$ の場合 (Fig. 11 (a)), 試験期間が 短いので腐食ピットなど局部的な腐食損傷は軽微であ った. $\sigma_{a}=11.5 \mathrm{~kg} / \mathrm{mm}^{2}$ の場合 (Fig. $11(\mathrm{~b})$ ), 腐食 ピットの成長や腐食ピットを起点とした大きな局部的 な溶解が認められ，类た近接の腐食ピットは合体して いるのが観察された。試験片断面には主き裂以外に $600 \mu \mathrm{m}$ 程度の微視き裂が存在し, 応力軸にほぼ一直 線に成長していた． $\sigma_{a}=6.5 \mathrm{~kg} / \mathrm{mm}^{2}$ で未破断の場合 (Fig. 11 (c)), 試験時間が約300時間と長いため腐食ピ ットは半円状に大きく成長していたが，微視き裂の長

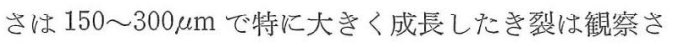
れなかった。な特 $3000 \mathrm{ppm} \mathrm{NaNO}$ 溶液中に特ける 試験片には，腐食ピットや微視さ裂などの腐食痩労損 傷は特に認められなかった。

腐食ピットルついてはむしろ腐食疲労損傷の 結果であるとの説がある。しかしながら本実験 系では上述のように試験期間が短くても腐食ピ ットが存在し, 腐食ピットの形状扣よびその大 ささは負荷応力と試験期間に依存することがわ かった。爽た微視き裂起点部には必ず腐食ピッ トが存在し, 腐食ピットの形状と大きさが, 腐 食疲学損傷被害の評洒に有效であると考光られ る。遠藤, 駒井らは, $1 \%$ 食塩水特よび $0.3 \mathrm{~N}$ 塩酸中に拈ける疲労強度と動的耐食性, 切欠さ 感受性之の相関性について検討し, 式(2)を提案 した. 一方著者らは前報で, 無負荷状態での腐 食減量から求めた平均腐食深さ $d$ と応力振幅下 に打ける最大腐食ピット深さとの比で定義され る孔食係数 $f_{p}$ 哇導入し, 式(2)の右辺老式(3)の よらに展開した。

$$
(k-1) / \eta=K \cdot \sqrt{ } i_{c o} / s
$$

ここで $k$ : 腐食效果(大氮中疲労強度 $\sigma_{a}$ 之腐食疲労強度 $\sigma_{a c}$ の比）

$\eta$ : 切欠き感度

$i_{c o}:$ 静的耐食性

$s$ : 動的耐食性

$K:$ 比例係数

$$
\left(i_{c o} / s\right) \propto(d / p)=\left(1 / f_{p}\right)
$$

な招本実験では試験片の主き裂近傍の $15 \mathrm{~mm}$ 

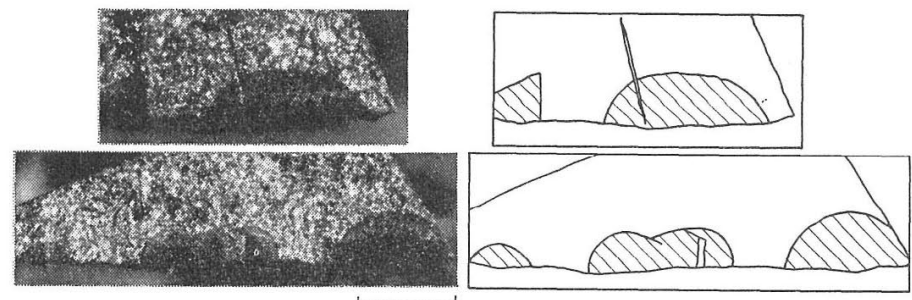

$1 \mathrm{~mm}$

$\left(\sigma_{\alpha}=10.5 \mathrm{~kg} / \mathrm{mm}^{2}, N_{f}-1.95 \times 10^{6}\right.$ cyclcs $)$

Fig. 13. Shape of microcracks occurring on roughly machined specimen fatigue-tested in ASTM solution at $80^{\circ} \mathrm{C}$.

程度の断面を钼察し，その断面に叔ける腐食ピット深 さの極大值を最大腐食ピット深さゃとした. Table IV には一部の應食痩労試験片についての断面観察結果か ら, 最大腐食ピットの深さ $p$ 党求めて孔食係数 $f_{p}$ ? 算出し， $(k-1)$ 之 $\left(1 / f_{p}\right)$ との関係をまとめた，平均 腐食深さ $d$ は試験時間の久比例するが，最大腐食ピ ット深さ $p$ は, 負荷応力之試験時間倍存している。

Table IV. Comparison between the term $(k-1)$ and the term $\left(1 / f_{p}\right)$.

\begin{tabular}{l|l|l|l}
\hline$k-1$ & $d(\mathrm{~mm})$ & $p(\mathrm{~mm})$ & $1 / f_{p}$ \\
\hline 0 & $8.06 \times 10^{-5}$ & $3.50 \times 10^{-2}$ & $2.30 \times 10^{-3}$ \\
0.21 & $6.83 \times 10^{-4}$ & $6.07 \times 10^{-2}$ & $1.13 \times 10^{-2}$ \\
$0.54^{*}$ & $6.58 \times 10^{-3}$ & $6.76 \times 10^{-2}$ & $9.73 \times 10^{-2}$ \\
\hline
\end{tabular}

* $\sigma_{a c}=6.5 \mathrm{~kg} / \mathrm{mm}^{2}, N_{f}>1.07 \times 10^{7}$ cycles

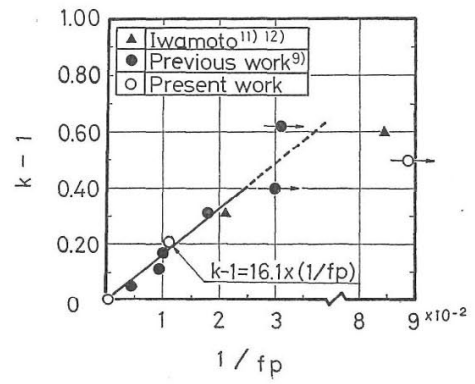

Fig. 12. Correlation between the term $(k-1)$ and the term $\left(1 / f_{p}\right)$.

Fig. 12 は $80^{\circ} \mathrm{C}$ ASTM 腐食水中に括忊る $\mathrm{Cr}-\mathrm{Mo}$ 鋳鋼の平面曲げ疲学試験の腐食效 果 $k$ 之孔食係数 $f_{p}$ との関係を示したもの で，前報で報告したＳ25Cおよび S35C，

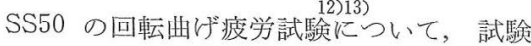
㸡面の観察結果炎併記した。 Fig.12 少 ら清水中に特汀る $\mathrm{Cr}-\mathrm{Mo}$ 鋳鋼の $(k-1)$ と $\left(1 / f_{p}\right)$ の関係は，前報で報告した試験 結果とほ湾一致することがわかった。しか しながら，腐食効果に走正しく評価するに は， $(k-1)>0.40$ の低応力側（長時間側） 昭和59年12月
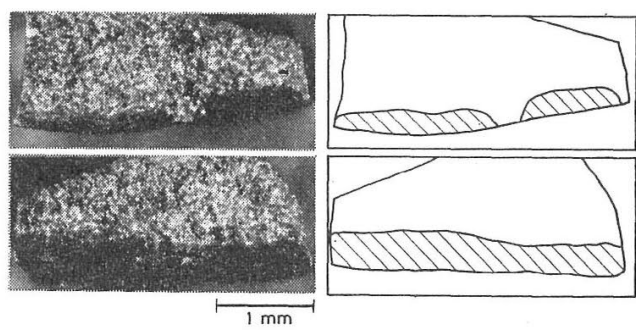

$\left(\sigma_{\alpha}=8.5 \mathrm{~kg} / \mathrm{mm}^{2}, \quad N_{f}=1.33 \times 10^{7}\right.$ cycles)

Fig. 14. Shape of microcracks occurring on roughly machined specimen fatigue-tested in ASTM solution at $80^{\circ} \mathrm{C}$.

そ和ける多くの実駼結果が必要で岁る。

つづいて腐食疲学試唡片の短冊状の小試片をぜい性 破断し，その破面を観察して試験片に発生した微視き 裂の形状を検討した．Fig. 13，14 は粗仕上試験片に ついての観察結果の一例で, $\sigma_{a}=10.5 \mathrm{~kg} / \mathrm{mm}^{2}, N_{f}=$ $1.95 \times 10^{6}$ 回拉よび $\sigma_{a}=8.5 \mathrm{~kg} / \mathrm{mm}^{2}, N_{f}>1.33 \times 10^{7}$ 回（未破断）の結果で㘯る。応力振幅 $\sigma_{a}=10.5 \mathrm{~kg} /$ $\mathrm{mm}^{2}$ の場合 (Fig. 13) には，微視き裂は半だ円状を 呈していたが， $\sigma_{a}=8.5 \mathrm{~kg} / \mathrm{mm}^{2}$ (Fig. 14) では，負 何応力が低く腐食期間が長いので微視き裂は互いに合 体して試験片表面に沿って長く伸び，試験片内部への 進展はわずかであった。

つぎに走查型電顕を用いて微視き裂を観察した。 Fig. 15 㜫視き裂進展域の破面樣相で，応力振幅 $\sigma_{a}$

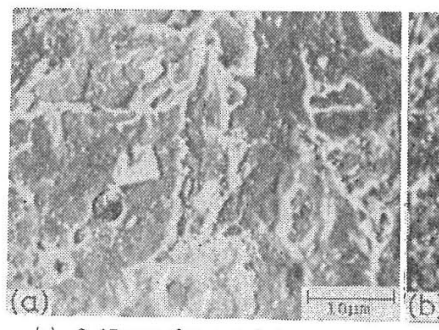

(a) $0.15 \mathrm{~mm}$ from origin; $\sigma_{Q}=$ $10.5 \mathrm{~kg} / \mathrm{mm}^{2}, \quad N_{f}=1.95 \times 10^{6}$ cycles.

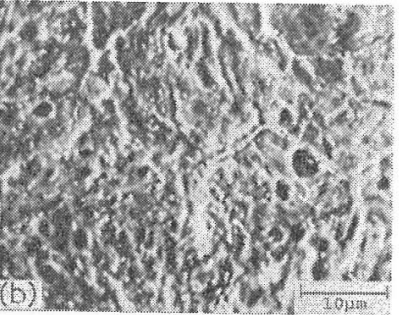

(b) $0.20 \mathrm{~mm}$ from origin; $\sigma_{\alpha}=$ $8.5 \mathrm{~kg} / \mathrm{mm}^{2}, \quad N_{f}>1.33 \times 10^{7}$ cycles.

Fig. 15. SEM micrographs of microcracks occurring on roughly machined specimen fatigue-tested in ASTM solution at $80^{\circ} \mathrm{C}$ 
$=10.5 \mathrm{~kg} / \mathrm{mm}^{2}$ (Fig. 15 (a)) では比較的平坦な粒内 破面, $\sigma_{a}=8.5 \mathrm{~kg} / \mathrm{mm}^{2}$ (Fig. 15(b)) では腐食期間が 長いため著しい腐食損傷を受けて不明りょらな破面と なっているが，粒界破面様相が観察された。いずれの 場合にも微視き裂の起点部には腐食ピットが存在して いた.

なお精仕上と粗仕上試験片の腐食疲労損傷状沉抢よ び腐食疲労破面様相に差違はなく, その腐食疲労損傷 に及ぼす表面仕上げの影響は認められなかった。

\section{5 結 論}

比較的大型の $\mathrm{Cr}-\mathrm{Mo}$ 鋳鋼試験片について腐食疲労 試験のできる平面曲げ試験装置を製作し， $80^{\circ} \mathrm{C}$ ASTM 腐食水抏よび $\mathrm{NaNO}_{2}$ 添加溶液中で疲労試験を行い, 腐食疲労強度に及ぼす表面仕上げの影響, $\mathrm{NaNO}_{2}$ に よる腐食疲労防止効果和よび試験片に生じた腐食疲労 損傷について検討した. 得られた結果を要約すると次 のと抢りである。

（1） 精仕上試験片（表面粗さ $R<2 \mathrm{~s}$ )，粗仕上試験 片 $(R \simeq 20 \mathrm{~s})$. 特よびショット・ブラストされた鋳肌付 試験片には明りょうな大気中疲労限度が存在し, 粗仕 上試験片の疲労限度は精仕上試験片のそれの約 $90 \%$ に 低下する。

（2）鋳肌付試験片の疲労強度は精仕上試験片，粗仕 上試験片のとれに比べ著しく上昇する.疲労強度上昇 の要因として，ショット・ブラストされた鋳肌表面層 に括ける圧縮残留応力の存在が考壳られる.

（3） $80^{\circ} \mathrm{C}$ ASTM 腐食水中に和訬る精仕上試験片括 よび粗仕上試験片の疲労強度はほぼ同程度であり, 表 面粗さの影響は認められない.ショット・ブラストさ れた鋳肌付試験片の腐食疲労強度は, 低応力側でその 強度低下率が比較的少ない。

(4) $3000 \mathrm{ppm} \mathrm{NaNO}_{2}$ 添加溶液中に抢ける 精仕上 試験片, 粗仕上試験片の疲労強度は大気中疲労強度に 回復し, 大気中之同程度の疲労限度が存在する.

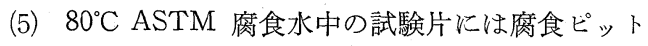
や微視き裂が存在する。腐食ピットや微視き裂の発生 箇数, 形状拉よび大きさは, 負荷応力と試験期間に依 存する. 一方 $3000 \mathrm{ppm} \mathrm{NaNO}_{2}$ 添加溶液中の試験
片には，腐食ピットや微視き裂などの腐食疲労損傷は 認められない。

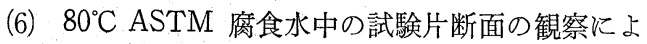
れば，負荷応力が比較的高い場合，微視き裂は半だ円 状である. 負荷応力が低く腐食期間が長い場合, 微視 き裂は互いに合体し試験片表面に沿って長く伸びてい る.

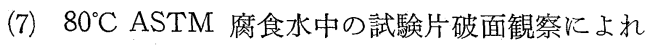
ば, 微視き裂の起点部には必ず腐食ピットが存在し, 負荷応力が低い場合粒界破面が観察される.

（8）精仕上試験片と粗仕上試験片の腐食疲労損傷に 差違はなく, 表面仕上げの影響は認められない。

本研究の一部が日本造船研究協会第 164 研究部会の 研究として行われたことを付記し，関係各位に謝意を 表します。

1) ASTM D $2570-73$.

\section{考文 献}

2）三浦健藏，大井利継，熊田 誠，三宅良昭，三井造船技 報, 第116号, p. 52 (1982).

3）日本機械学会編，“金属材料疲れ強さの設計資料，II表 面効果”, p. 4 . (1973).

4）川田雄一，“金属の疲労と設計”，第7 章（1982）オーム 社.

5）青山咸恒，伊藤三史，浅井昇次，材料， 27，895 (1978).

6) 三浦健蔵, 熊田 誠, 大井利繼, 材料, 33，692: (1984).

7) 川田雄一, “金属の疲労と設計”, 第 9 章 (1982) オーム 社.

8) D. J. Duquette and H. H. Uhlig, Trans. ASM, 61, 449 (1968).

9）遠藤吉郎, 駒井謙治郎, 中室直之, 日本機械学会論文集 (第1 部), 35, 2154 (1969).

10）三浦健蔵，熊田 誠，大井利継，材料， 31，64 (1982).

11) H. H. Uhlig, "Corrosion and Corrosion Control", Chap. 2 (1971) John Wiley \& Sons, New York.

12）岩之兼敏，日本機械学会論文集（第 1 部）， $30 ， 500$ (1964).

13）岩之兼敏， 日本機械学会論文集（第 1 部）， 34， 1345 (1968). 